УДК $553.98(571.1 / 5)$

\title{
О ВОЗМОЖНОЙ НЕФТЕГАЗОНОСНОСТИ РИФТОГРАБЕНОВ УЧУРСКОЙ И МАЙСКОЙ ЗОН НА ЮГО-ВОСТОЧНОМ ФЛАНГЕ АЛДАНСКОЙ АНТЕКЛИЗЫ (Сибирская платформа)
}

\author{
Хомич В. Г., Борискина Н. Г. \\ ФГБУН Дальневосточный геологический институт ДВО РАН, г. Владивосток \\ E-mail:khomich79@mail.ru
}

\begin{abstract}
На основе сравнительного анализа особенностей строения и геодинамических условий развития нефтегазоносных сооружений Западно-Сибирской плиты, Сибирского кратона, осадочных бассейнов Северного Сахалина и его шельфов обоснована возможность выявления залежей углеводородов в рифтограбенах и депрессиях Учурской и Майской структурно-фациальных зон Алданской антеклизы юго-восточной окраины Сибирской платформы.
\end{abstract}

Ключевые слова: Алданская антеклиза, рифтограбены, депрессии, Сибирский кратон, палеотрансформные разломы, углеводороды, геохимические аномалии.

DOI: $10.34078 / 1814-0998-2020-2-34-48$

\section{ВВЕДЕНИЕ}

При оценке перспектив нефтегазоносности малоисследованных площадей Дальнего Востока России основное внимание уделяют сравнительному анализу литологического состава, структурных особенностей бассейнов осадконакопления и последующему их сопоставлению с хорошо изученными (типоморфными) объектами, где выявлены промышленные запасы углеводородов (УВ) (Варнавский, Кузнецов, 2011; Баженова, Маргулис, 2014; Кузнецов, Варнавский, 2018). Вместе с тем в последние десятилетия к оценке перспективности осадочных бассейнов привлекаются нетрадиционные данные о вероятном мантийно-абиогенном источнике скоплений УВ и их глубинном флюидогеодинамическом контроле (Сапрыгин, 1997; Сорохтин и др., 2001; Харахинов, 2010; Берзин и др., 2019). Приводятся также доказательства влияния структур фундамента на размещение залежей в осадочно-породных бассейнах (Иванов и др., 2018).

В свете современной обеспеченности РФ нефтегазовым сырьем и обнаружением крупных его месторождений в типичных платформенных условиях (Конторович и др., 1996) многие специ-

(C) Хомич В. Г., Борискина Н. Г., 2020 алисты считают весьма актуальной проблему исследования краевых частей Сибирского (СевероАзиатского) кратона, в строении которых участвуют докембрийские комплексы. Предполагается, что в последних при взаимодействии с мобильными структурами обрамления могли активно проявиться деструктивные процессы, повлиявшие на формирование и сохранение залежей УВ (Кузнецов, Варнавский, 2018). Для оценки вероятной нефтегазоносности Алданской антеклизы и Алдано-Майского осадочного бассейна В. Е. Кузнецов и В. Г. Варнавский проанализировали литолого-стратиграфические особенности венд-рифейских комплексов западной, восточной краевых частей Сибирской платформы и констатировали, что на ее востоке при обилии битумопроявлений пока не выявлено промышленных залежей нефти и газа. При том, что первые сведения о наличии жидкой нефти на северном склоне Алданской антеклизы были получены еще в довоенные годы. На западной же окраине платформы такие залежи промышленных категорий уже разведаны (Конторович и др., 1996). Они размещены в рифейских отложениях, стратотипы которых известны и в Алданской антеклизе (рис. 1). Приведем сравнительную характеристику разрезов окраин платформы. 


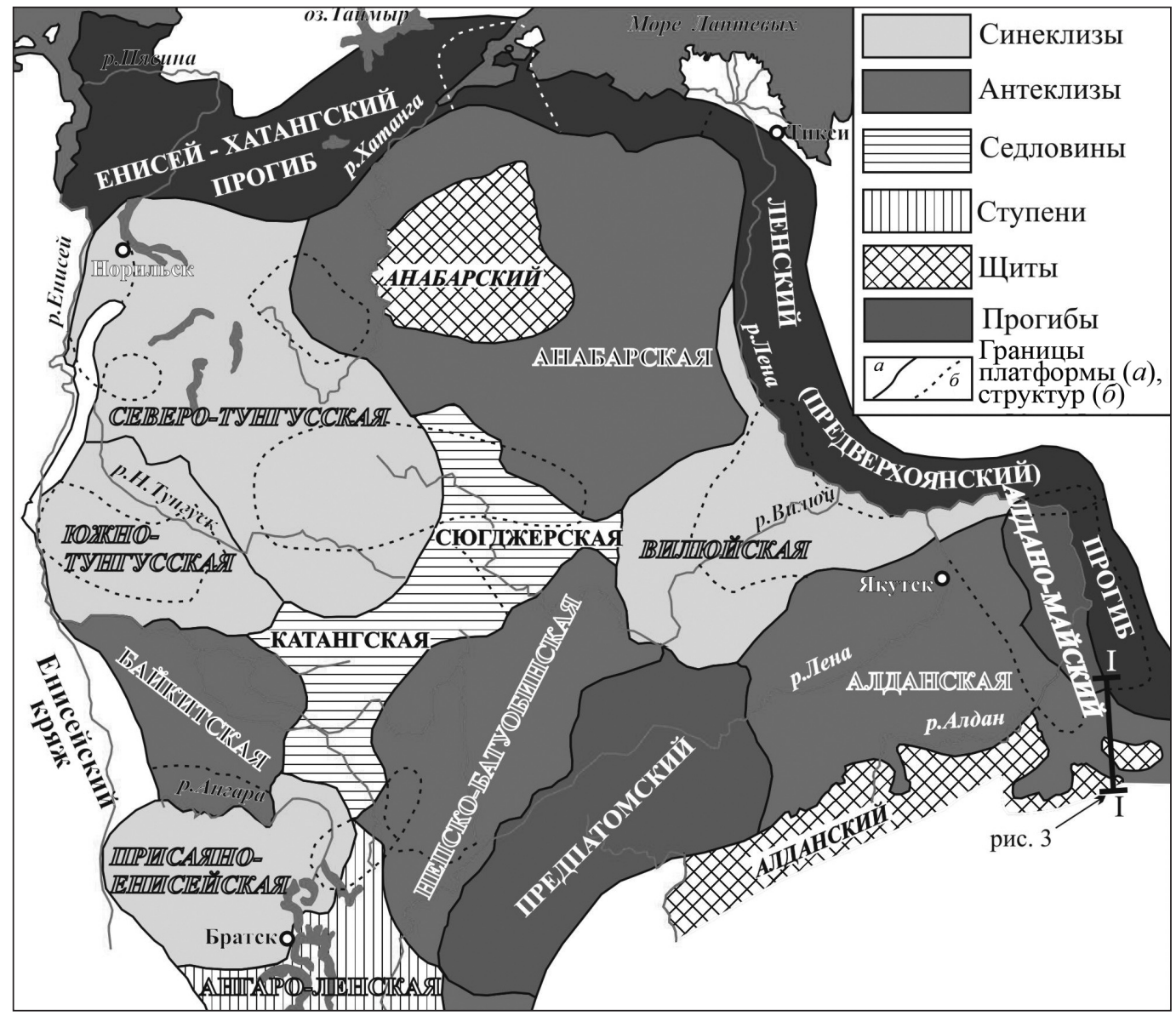

Puс. 1. Обзорная схема районирования Сибирской платформы (Цит. по: Старосельцев и др., 2013 из Шемин и др., 2018) с некоторыми изменениями и дополнениями

Fig. 1. Summary chart of the Siberian platform zoning. After Staroseltsev et al., 2013 from Shemin et al., 2018, modified and amended

\section{ОБОБЩЕННАЯ ХАРАКТЕРИСТИКА РАЗРЕЗОВ ЗАПАДНОЙ И ЮГО-ВОСТОЧНОЙ КРАЕВЫХ ЧАСТЕЙ СИБИРСКОЙ ПЛАТФОРМЫ}

На западной окраине платформы в Байкитской антеклизе рифейские отложения плащеобразно (с несогласием) перекрыты венд-ордовикскими толщами плитного комплекса. Кембрийская часть разреза сложена доломитами, содержащими пласты каменной соли. Вендские карбонатноглинистые отложения и доломиты кембрия часто выполняют роль флюидоупоров. Ордовикские терригенно-карбонатные пачки распространены здесь фрагментарно. Примечательно, что в приподнятых блоках кристаллического основания (из архейско-протерозойских гранитов и гранитогнейсов) проявлены мощные коры выветривания. Они обнаружены в нижней половине разреза рифея и у предвендской поверхности углового и стратиграфического несогласий, образуя, наряду с другими коллекторами, природные резервуары, благоприятные для сбора и консервации залежей УВ.

На восточной и юго-восточной окраине платформы (Алданская антеклиза) так же, как и в за- падной, выделяют три структурных этажа: из архейско-протерозойских магматических и метаморфических образований, до- и рифейских рифтогенных серий, разделенных несогласиями (с корами выветривания), перекрытых вендкембрийскими свитами плитного комплекса (рис. 2).

Наиболее древние слабодислоцированные отложения чехла распространены в нескольких рифтограбенах Учурской структурнофациальной зоны (СФ3), расположенной на юговосточном фланге антеклизы. Здесь в составе улканской, уянской и учурской серий различают до 8 красноцветных толщ с многочисленными прослоями вулканитов (низы разреза) и доломитов. Средний и верхний рифей представлены аимчанской, керпыльской и уйской сериями, разделенными несогласиями и корами выветривания. Серии сложены терригенными песчаноалевро-аргиллитовыми толщами с доломитами, битуминозно-глинистыми, известковистыми отложениями. Накопления лахандинской серии в Учурской СФЗ отсутствуют (Кузнецов, Варнавский, 2018). Рифейские комплексы, подвергшие- 


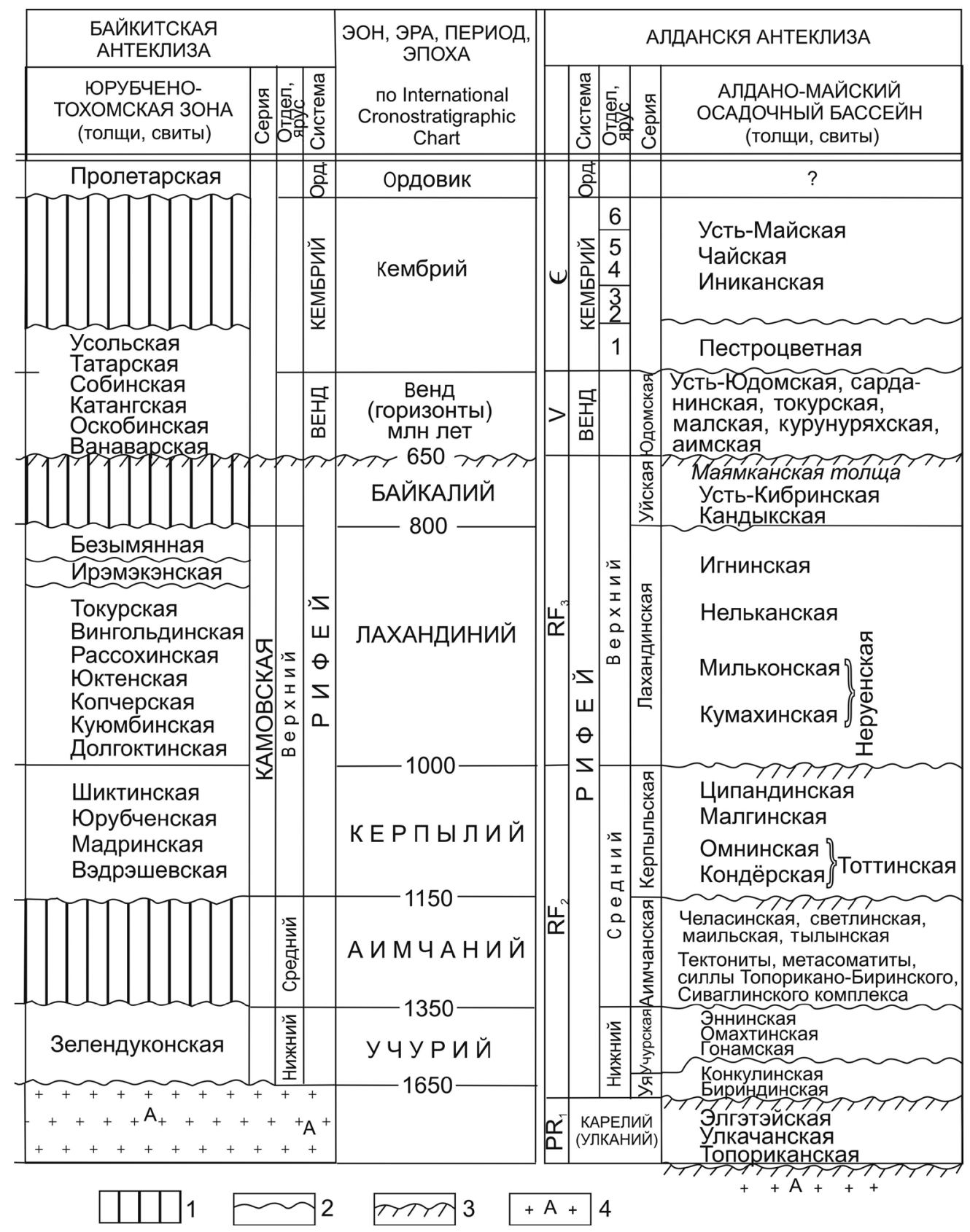

Puc. 2. Схема сравнительной стратиграфии Байкитской и Алданской антеклиз (по: Кузнецов, Варнавский, 2018) с изменениями: 1 - перерывы в осадконакоплении; 2 - несогласия; 3 - коры выветривания; 4 - гнейсы, гранитоиды, метаморфиты кристаллического основания, AR

Fig. 2. Comparative stratigraphy of the Aldan and the Baikit anteclise. After Kuznetsov, Varnavsky, 2018, modified: 1 - breaks in sedimentation; 2 - disconformities; 3 -weathering crusts; 4 - gneisses, granitoids, metamorphites of the crystalline base, AR

ся эрозии и процессам выветривания, перекрыты отложениями венд-кембрийского плитного комплекса из почти двух десятков коррелятно сопряженных свит (см. рис. 2). Этот комплекс представлен толщами конгломератов, песчаников, алевролитов, доломитов и доломитизированных известняков, сменяющихся на границе нижнего и среднего кембрия переслоем глинистых, черных листоватых горючих и кремнистых сланцев (Кузнецов, Варнавский, 2018).
Из сопоставления литологического состава и возраста разрезов Байкитской, Алданской антеклиз, а также сравнительного анализа истории их формирования, изложенного в серии публикаций (Варнавский, Кузнецов, 2011; Харахинов и др., 2011; Баженова, Маргулис, 2014; Кузнецов, Варнавский, 2018), со всей очевидностью следует значительная схожесть фациальных, геодинамических условий рифейского осадконакопления, происходивших в авлакогенную стадию станов- 
ления чехла Сибирской платформы. Также сопоставимы (литологически и седиментационно) их вендские и нижнекембрийские терригеннокарбонатные разрезы.

Нефтегазоносность юго-восточной периферийной части платформы и ее известных сегментов, где кратонизированная кора взаимодействовала с более молодыми подвижными структурами обрамления, представляется некоторым исследователям проблемной. В связи с этим весьма примечательны материалы А. Е. Лукина, В. В. Донцова, а также В. В. Харахинова с соавторами (2011) о существовании признаков взаимодействия пород продуктивных комплексов Байкитской антеклизы с нетрадиционными флюидными углеводородсодержащими разломными системами глубинного заложения. Материалы и выводы этих геологов подкрепляются обнаружением в керне пород местного продуктивного комплекса микрочастиц самородных металлов и интерметаллических соединений.

Возвращаясь к характеристике разреза Алданской антеклизы, выполненной в основном по материалам В. Г. Варнавского и В. Е. Кузнецова (2011), В. Е. Кузнецова и В. Г. Варнавского (2018), обращаем внимание на присутствие здесь среди осадочных толщ юго-восточного фланга СевероАзиатского кратона магматических образований, включая специфические раннемеловые (Ронкин и др., 2013) зональные щелочно-ультраосновные массивы кондерского комплекса (Гурович и др., 1994). Приведем более подробное описание геологии этой части кратона.

\section{ОСОБЕННОСТИ ГЕОЛОГИЧЕСКОГО СТРОЕНИЯ ЮГО-ВОСТОЧНОЙ ЧАСТИ СЕВЕРО-АЗИАТСКОГО КРАТОНА}

Юго-восточному флангу кратона присущи две яркие особенности: наличие дорифейских осадочно-вулканогенных толщ и широкая распространенность разновозрастных магматических образований. Формирование гранитоидов и базитов повышенной щелочности, ассоциирующих с протоплатформенными осадочно-вулканогенными толщами улканского комплекса (1.77-1.7 млрд лет), соотносят с мантийно-плюмовыми процессами, обусловившими развитие активного рифтогенеза и возникновение местного трехлучевого палеорифта (Гурьянов, Песков, 2015). Как уже отмечалось, у границ Алданского щита архейские метаморфические комплексы перекрываются многоярусным чехлом рифейских терригеннокарбонатных отложений, отображенных на рис. 2. Внимание авторов привлекли Учурская и Майская СФЗ, которые вмещают и горстовые поднятия (рис. 3).

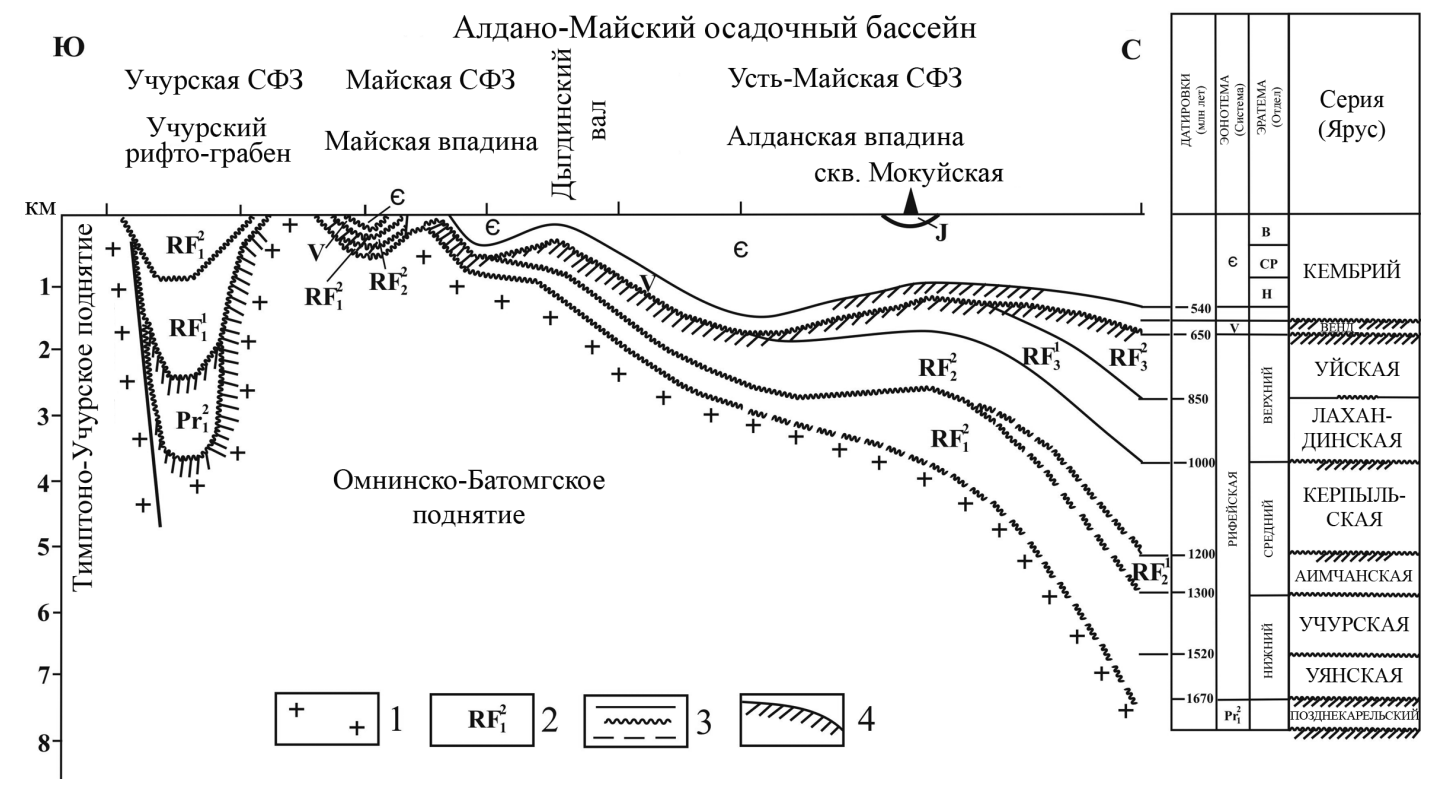

Puc. 3. Схематический разрез Алдано-Майского осадочного бассейна по субмеридиональному профилю I-I (по: Кузнецов, Варнавский, 2018) с незначительными изменениями: 1 - кристаллический фундамент Сибирской платформы; 2 - стратиграфические индексы подразделений осадочного чехла; 3 - границы между подразделениями осадочного чехла и кристаллического основания; 4 - коры выветривания. Положение профиля см. на рис. 1

Fig. 3. Schematic section of the Aldan-Maya sedimentary basin along sub-meridional Profile I-I. After Kuznetsov, Varnavsky, 2018, with minor modifications: 1 - crystalline basement of the Siberian platform; 2 - stratigraphic units of sedimentary cover; 3 - boundaries between units of the sedimentary cover and the crystalline base; 4 - weathering crusts. For the profile position, see Fig. 1 
Разновозрастные интрузивные образования представлены на их площади кольцевыми ультрамафит-щелочными (с карбонатитами) и ще- лочно-ультраосновными (с дунитовыми ядрами) плутонами (рис. 4).

Наиболее древними среди кольцевых плутонов - предвендскими ( 650 млн лет) и достаточ-
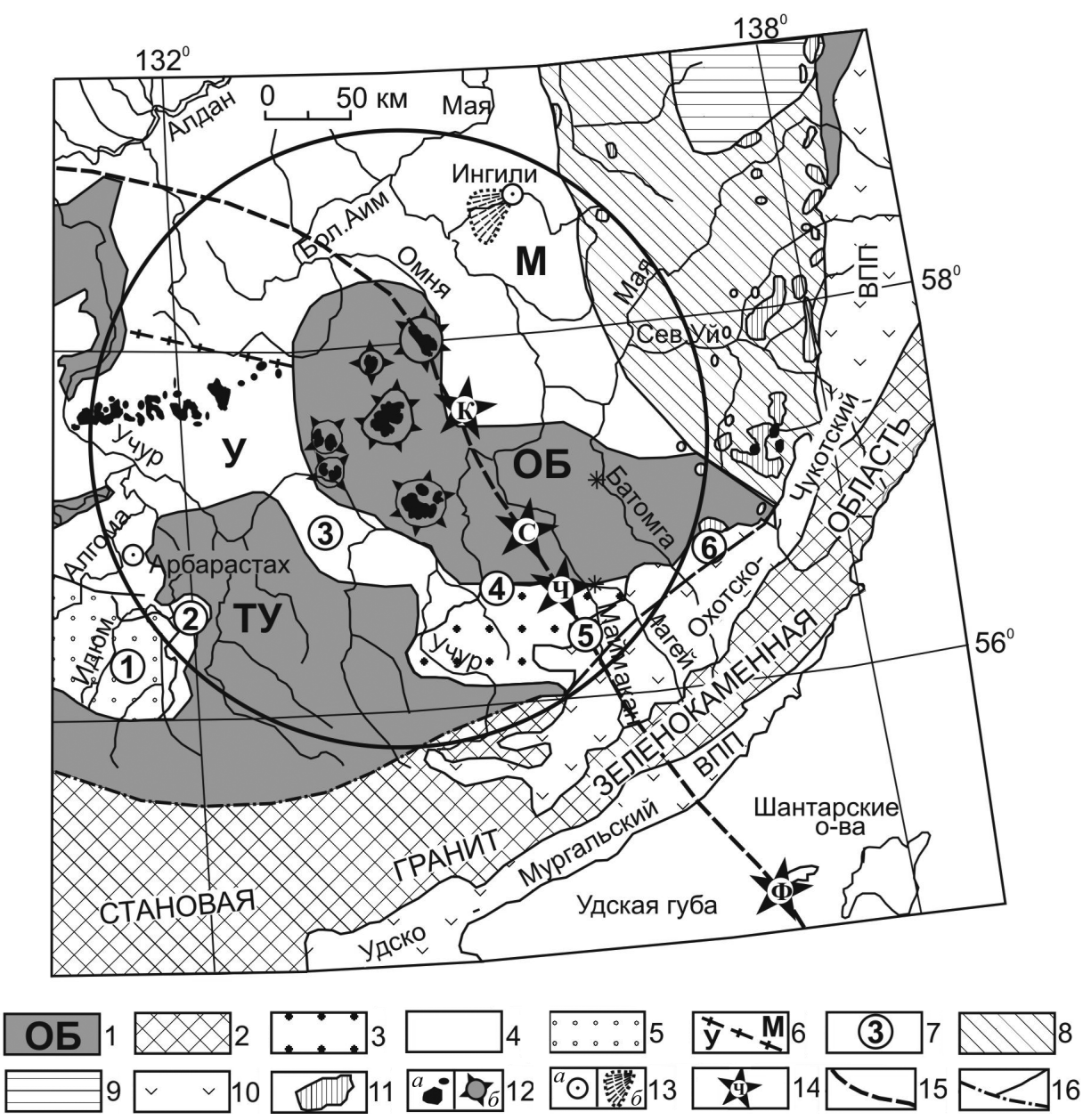

Puc. 4. Геологическая схема юго-восточного фланга Сибирского кратона (по: Гурович и др., 1994; Хомич, Борискина, 2013; Кузнецов, Варнавский, 2018) с изменениями и дополнениями: 1, 2 - области Алдано-Станового щита: 1 - Алданская гранулит-гнейсовая (ТУ - Тимптоно-Учурское, ОБ - Омнинско-Батомгское поднятия), 2 - Становая гранит-зеленокаменная; 3-5 - стратифицированные отложения платформенного чехла: 3 - протерозойрифейские (терригенно-вулканогенные) Улканского рифта, 4 - венд-кембрийские, 5 - позднемезозойские; 6 - граница Учурской (У) и Майской (М) СФЗ Алданской антеклизы; 7 - рифтограбены Учурской СФЗ: 1 - Токкинский, 2 - Амуликанский, 3 - Учурский, 4 - Верхне-Угаянский, 5 - Маймаканский, 6 - Верхне-Батомгский; 8, 9 - палеозойские $\left(\mathrm{C}_{1}-\mathrm{P}_{1}\right)$ образования Южно-Верхоянского орогенного пояса: 8 - Юдомо-Майское краевое поднятие, 9 - АллахЮньский синклинорий; 10 - позднемезозойские ВПП; 11 - высокощелочные интрузивные и субвулканические массивы джугджурского комплекса; 12 - юрско-меловые интрузивы $(a)$ и местные тектономагматические поднятия (б) Батомгского супертеррейна; 13 - карбонатитовые массивы $(a)$ и поля даек (трубок) кимберлитоподобных пород (б); 14 - зональные щелочно-ультраосновные (с ЭПГ) массивы (К - Кондер, С - Сыбах, Ч - Чад, Ф - Феклистов); 15 осевая зона Инагли-Кондер-Феклистовского магмо-металлогенического пояса; 16 - разломы разной глубинности. В большом круге - потенциально нефтегазоносные осадочно-породные бассейны

Fig. 4. Geological scheme of the Siberian Craton southeastern flank. After Gurovich et al., 1994; Khomich, Boriskina, 2013; Kuznetsov, Varnavskiy, 2018, modified and amended: 1, 2 - areas of the Aldan-Stanovoy shield: 1 -Aldan granulitegneiss (ТУ - Tympton-Uchur, ОБ - Omniya-Batomga uplifts), 2 - Stanovoy granite-greenstone; 3-5 - stratified sediments of the platform cover: 3 - Proterozoic-Riphean (terrigenous-volcanogenic), of the Ulkan rift, 4 - Vendian-Cambrian, 5 Late-Mesozoic; 6 - border of Uchur (Y) and Maya (M) SFZ of Aldan anteclise; 7 - riftgrabens of Uchur SFZ: 1 - Tokkin, 2 - Amulikan, 3 - Uchur, 4 - Verkhne-Ugayan, 5 - Maymakan, 6 - Verkhne-Batomga; 8, 9 - Paleozoic $\left(\mathrm{C}_{1}-\mathrm{P}_{1}\right)$ formations of the South-Verkhoyansk orogenic belt: 8 - Yudoma-Maya regional uplift, 9 - Allakh-Yun synclinorium; 10 - Late Mesozoic VPB; 11 - high-alkaline intrusive and subvolcanic massifs of the Dzhugdzhu complex; 12 - Jurassic-Cretaceous intrusives $(a)$ and local tectonic-magmatic uplifts (б) of the Batomga superterrane; 13 - carbonatite massifs $(a)$ and fields of dikes (tubes) of kimberlite-like rocks (б); 14 - zonal alkaline-ultrabasic (with PGE) massifs (K - Konder, C - Sybakh, Ч - Chad, $\Phi$ - Feklistov); 15 - axial zone of the Inagli-Konder-Feklistov magma-metallogenic belt; 16 - faults of different depths. The large circle embraces potentially oil-andgas bearing sedimentary-rock basins 
но крупными (до 40 м $^{2}$ ) являются карбонатитсодержащие Ингилийский и Арбарастахский, вероятно, принадлежащие единой тектонической зоне. Их геодинамическую позицию определяют приуроченностью к борту северо-восточного палеорифта, расчленившего лавразийскую часть Родинии (Кузьмин, Ярмолюк, 2014). Иное, западно-северо-западное простирание имеет Инагли-Кондер-Феклистовский магматический пояс, в котором сосредоточены позднемезозойские щелочно-ультраосновные (с дунитовым ядром) концентрически зональные плутоны, специализированные на Cr-PGE элементы. Благодаря сейсмотомографическим исследованиям установлена размещенность этого пояса над одной из палеотрансформных границ океанического слэба, стагнированного в транзитной зоне мантии (Khomich et al., 2014).

Отмеченные кольцевые (с дунитовым ядром) щелочно-ультраосновные массивы в совокупности с другими пространственно сближенными магматическими образованиями разной геохимической специализации, согласно исследованиям А. А. Маракушева и его соавторов (1990), возникли из единого расплава, в процессе кристаллизационной дифференциации. Этот вывод, имеющий исключительно важное значение, подтверждается многими современными авторами (Ронкин и др., 2013). Они считают дуниты типичными кумулятами. Окружающие их более поздние известково-щелочные, а затем субщелочные и щелочные породы натриевого и калиевого рядов представляются продуктами дальнейшей кристаллизации остаточных расплавов, насыщенных газо-водосолевыми флюидами.

Сходные ассоциации (трахиандезит-диоритгранодиоритовая, тефрит-фонолит-щелочно-трахитовая с сиенитами, фоидо-щелочно-сиенитовая и монцонит-сиенитовая) диагностированы в соседних Кеткапско-Юнской и Томптоканской магмо-металлогенических зонах. Новейшие определения возраста магматитов разными методами (K-Ar, U-Pb по цирконам и сфенам) свидетельствуют об их формировании в возрастном диапазоне 125.8-120.1 млн лет (Полин и др., 2012).

Среди платиноносных зональных (с дунитовым ядром) массивов, размещенных на Омнинско-Батомгском поднятии и по его обрамлению (см. рис. 4), наиболее известным является Кондерский (Гурович и др., 1994). Прямое датирование (112 7 млн лет) местной россыпной ферроплатины (Шуколюков и др., 2012) вполне согласуется с возрастом платиноносного дунита (124.9 \pm 1.9 и $125.8 \pm 3.8$ млн лет) (U-Pb метод системы «бадделеит - циркон», Ронкин и др., 2013). Имеются сведения о наличии молодых мафит- ультрамафитовых (с ЭПГ) плутонов и далеко к юго-востоку от поднятия: на Шантарах, Нижнем Амуре (Khomich et al., 2018), восточном побережье о. Сахалин (Высоцкий и др., 1998; Леснов, 2015), где рудоносные и нефтегазоносные площади имеют общую геологическую границу западно-северо-западной ориентации (Сапрыгин, 1997; Тектоническое..., 2006).

Завершая краткую геологическую и минерагеническую характеристику позднемезозойских проявлений эндогенного оруденения в юговосточной части Сибирского кратона, отметим, что, во-первых, основная их часть формировалась в возрастном диапазоне 130-110 млн лет, т. е. в барреме - апте, в тесной пространственновременной ассоциации с магматическими образованиями повышенной щелочности. Вовторых, все выявленные раннемеловые месторождения PGE и $\mathrm{Au}$ размещаются в породах фундамента кратона у границ с рифейскими терригенно-карбонатными толщами или среди последних (Полин и др., 2012; Khomich, Boriskina, 2012; Хомич, Борискина, 2013, 2018). Рассмотрим далее особенности размещения месторождений УВ на территории Сибири и Дальнего Востока России.

\section{ЗАКОНОМЕРНОСТИ РАЗМЕЩЕНИЯ МЕСТОРОЖДЕНИЙ УВ НА ЗАПАДНО- СИБИРСКОЙ ПЛИТЕ, СИБИРСКОЙ ПЛАТФОРМЕ И В АЗИАТСКО- ТИХООКЕАНСКОЙ МЕГАЗОНЕ ВЗАИМОДЕЙСТВИЯ}

Месторождения УВ Западной Сибири приурочены к пермо-триасовым рифтовым системам и структурам их обрамления (Зоненшайн, Кузьмин, 1992), что подтверждено вероятностностатистическим анализом и недавними геологогеофизическими исследованиями (Иванов и др., 2018). Рифтам в моделях глубинного абиогенного синтеза УВ придается контролирующее значение за счет наличия сопряженных с ними проницаемых разломных зон, дренирующих верхнюю мантию и поставляющих в земную кору горячие флюиды в виде $\mathrm{CO}_{2}, \mathrm{H}_{2}, \mathrm{H}_{2} \mathrm{O}, \mathrm{CH}_{4}$ и других соединений (Сорохтин и др., 2001). В развитии преобразований породных комплексов чехла плиты и формировании в нем складчатых структур главное место отводится фундаменту, деформации которого отразились на строении перекрывающих литокомплексов (Иванов и др., 2018). Рифтограбены Западно-Сибирской плиты фиксируются положительными магнитными, гравиметровыми аномалиями и повышенным тепловым потоком. При этом крупные месторождения нефти, размещенные в осадочном чехле, залегают поблизости от выступов сиалических блоков основания. Такие горсты сложены метаморфи- 
ческими сланцами и гранитоидами. Предполагается, что изостатическое «всплытие» горстов в позднем палеозое - раннем мезозое привело к формированию антиформ в осадочном чехле и заполнению их УВ. Типоморфными геохимическими элементами западносибирской нефти считаются платиноиды, V, Co, Ni и Cr, свойственные мантийным ультрабазитам (Иванов и др., 2018).

На западной окраине Сибирской платформы весьма крупная - Юрубчено-Тохомская - нефтегазоносная зона также размещена в пределах центрального (Куюмбинского) рифта на Камовском своде Байкитской антеклизы (Конторович и др., 1996). Важно отметить, что в пределах рифта находится ограниченный глубинными разломами горст из гранито-гнейсов и гранитов кристаллического фундамента. Как отмечено выше, в Алданской антеклизе и ее Учурской, Майской СФ3 (на юго-восточной окраине платформы) также имеются горстовые поднятия фундамента (см. рис. 1).

Обратившись далее к структурам российской части Азиатско-Тихоокеанской мегазоны взаимодействия, отметим, что здесь выявлено несколько продуктивных зон нефтегазонакопления. Самая известная среди них - Северо-Сахалинская.

Геологические комплексы о. Сахалин причисляют к двум структурным этажам: докайнозойскому (палеозой-мезозой-палеоценовому) основанию и кайнозойскому (эоцен-плейстоценовому) чехлу. Докайнозойские комплексы претерпели несколько структурных перестроек, обусловленных аккреционно-коллизионными, рифтогенными процессами, в связи с этапами развития и деструкции, континентального роста ВосточноАзиатской активной окраины (Жаров, 2004). Кайнозойский чехол включает накопления угленосных формаций, возникших на границе мела и палеогена также в условиях рифтогенеза. Еще одна кардинальная смена геодинамического режима (рифтогенеза на орогенез) произошла на границе миоцена - плиоцена и сопровождалась интенсификацией процессов складкообразования, формированием сдвигов и взбросо-сдвигов. Их фрагменты обладают повышенной флюидонасыщенностью (Никифоров и др., 2018). Шовные сдвиговые зоны острова имеют протяженность многие сотни и ширину в десятки километров. Они довольно отчетливо проявлены в виде уступов рельефа и положительными аномалиями в магнитном и гравитационном полях. Современная структура острова - с поднятиями, опусканиями и развитыми складчатыми сооружениями оформилась на рубеже плиоцена - квартера (Гладенков и др., 2002).

Детальными исследованиями нефтегазовых полей острова и его шельфа установлена исключительно важная роль сдвиговой тектоники в создании благоприятных условий для появления флюидоподводящих каналов и непроницаемых флюидоупоров при дальнейшем формировании ореолов и зон нефтегазонакопления. Эти факты учтены в известной глубинно-фильтрационной модели накопления УВ (Сапрыгин, 1997; Харахинов, 2010). В ней основными факторами возникновения соответствующих месторождений являются глубинные разломы, контролирующие создание присдвиговых бассейнов растяжения и путей миграции флюидопотоков. Важны также особые сочетания в осадочных бассейнах породных комплексов повышенной проницаемости и флюидоупоров, влиявших на размещение залежей угеводородов и их последующее сохранение. Сахалинские магистральные флюидопроводящие системы северо-западного простирания продолжаются в юго-восточном направлении к о-вам Уруп, Итуруп и Кунашир Курильской островодужной системы (рис. 5). Примечательно также, что придонноморские залежи газогидратов, выявленные в Охотоморье почти у всех структур газового просачивания, в основном приурочены к зонам таких разломов. Одна из линейных зон шельфовых газогидратов имеет протяженность около 130 км. В ее пределах выявлено более 150 очагов разгрузки углеводородных газов (Касаткин, Обжиров, 2018).

Другие участки южного Охотоморья с максимальными потоками $\mathrm{CH}_{4}$ также проецируются на разломы глубокого заложения. Самый крупный из современных потоков газа, выявленный в морской среде Южно-Охотской зоны, был высотой 2000 м, мощностью 2.99 кг/(км² · сут) (Мишукова и др., 2017). Зафиксирована синхронность его активации с глубинным землетрясением 14 августа 2012 г., гипоцентр которого был в 625.9 км от поверхности (Касаткин, Обжиров, 2018). Причинность подобных потоков и выбросов объясняется, в соответствии с моделью флюидогеодинамики, воздействием глубокофокусной сейсмотектонической активизации.

Известны в Охотоморье потоки УВ и в местах водно-флюидной разгрузки многих наземных вулканов Курильской островодужной системы. Особенно они характерны для ее южного звена: влк. Менделеева, Головнина (о. Кунашир), влк. Медвежьего (о. Итуруп) и др. Главным компонентом (до 90-95 об.\%) дефлюидизации вулканов являются пары воды. Среди других соединений установлены $\mathrm{CO}_{2}, \mathrm{CO}, \mathrm{HCL}, \mathrm{HF}, \mathrm{H}_{2} \mathrm{~S}, \mathrm{NH}_{3}$, $\mathrm{N}_{2}, \mathrm{CH}_{4}, \mathrm{HCNS}, \mathrm{F}_{4}, \mathrm{~B}(\mathrm{OH})_{3}$, Ar и др. (Ткаченко и др., 1992; Шакиров, 2014). В активно газирующих высокотемпературных сольфатарах, в термальных водах и грязевых котлах присутствуют, нл/л: метан - до 800, этан - до 40, этилен - до 100, пропан, бутан, сложные комплексные соединения УВ с хлором, фосфором, рением и плати- 
ной, другими благородными металлами (Korzhinskii et al., 1994; Yudovskaya et al., 2006; Дистлер и др., 2008).

Газовая фаза грязевых вулканов провинции в основном представлена метаном (до 95 об.\%) в присутствии $\mathrm{N}_{2}$ и $\mathrm{CO}_{2}(<10-15$ об.\%) (Шакиров и др., 2012). В пользу мантийной природы газов свидетельствуют изотопные данные соответствующей фазы минеральных вод Синегорского месторождения и Южно-Сахалинского грязевого вулкана (Челноков и др., 2015). В связи с этим отметим, что специализированными геохимическими исследованиями смолистоасфальтовых веществ из нефтяных месторождений северного Сахалина установлены значимые количества ЭПГ, г/т: $\mathrm{Ru}-0.3, \mathrm{Rh}-0.1$, $\mathrm{Ir}-0.12, \mathrm{Pt}-0.52$, Pd - 0.92 (Mapaкушев и др., 2014).

Таким образом, приведенные сведения о наличии УВ в российском фрагменте АзиатскоТихоокеанской мегазоны взаимодействия характеризуют регион в качестве неординарной провинции сосредоточения нефтегазовых полей и соответствующих потоков, возникших под влиянием глубинной геодинамики. К числу ее ярких особенностей относится не только углеводородная специализация, но и принадлежность наиболее мобильной части одноименной зоны конвергенции. Этот вывод подтверждается новыми материалами об открытии первой абиссальной нефтегазоносной провинции в прироссийской части ложа Тихого океана, расположенной между Курило-Камчатским желобом и поднятием Шатского (Ломтев и др., 2016). Здесь известны (см. рис. 5) протяженные (более 1000 км), глубинные (до 100 км), долгоживущие (J-Q) разломные зоны трансформного типа: Уруп, Итуруп и Носаппу (Тускарора). Вблизи последней, на океанском дне, японскими геологами обнаружены малообъемные

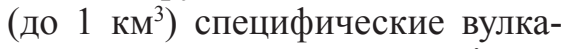
нические сооружения «petit-spot», сложенные преимущественно шошонитами (Ogawa, Hirano,

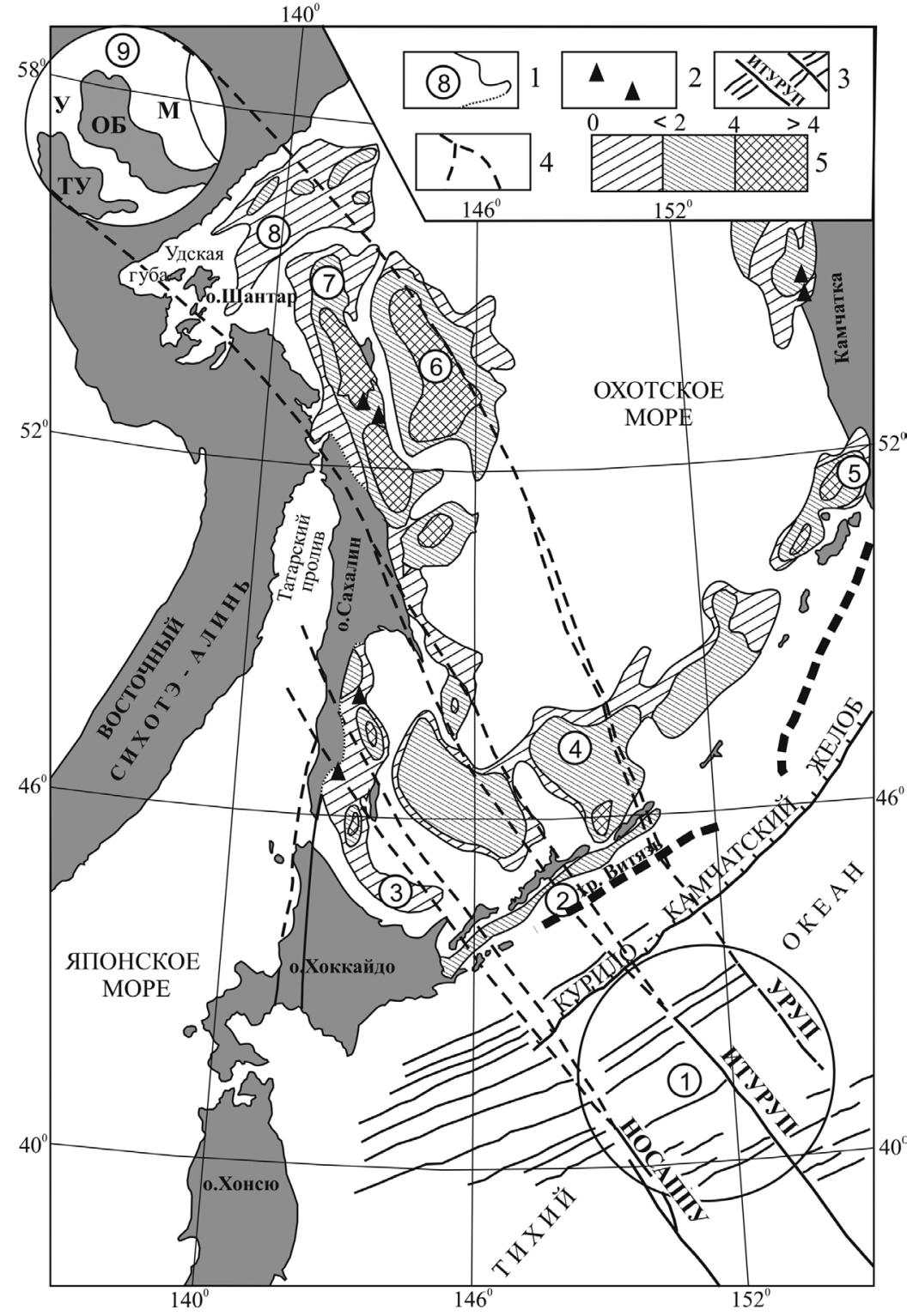

Puc. 5. Схема размещения потенциально- и нефтегазоносных терра-аквальных бассейнов Южной части Охотского моря и Тихого океана (по: Тектоническое..., 2006; Norton, 2007; Ломтев и др., 2016; Khomich et al., 2019) с дополнениями: 1 - бассейны и их границы: 1 - Океанский, 2 - Срединно-Курильский, 3 - Южно-Сахалинский, 4 - Южно-Охотский, 5 - Голыгинский, 6 - Дерюгинский, 7 - СевероСахалинский, 8 - Шантарский, 9 - Учуро-Майский (см. рис. 4); 2 некоторые известные месторождения УВ; 3 - разломные зоны трансформного типа и линейные магнитные аномалии океанического дна; 4 - прочие разломы; 5 - предполагаемая глубина очагов генерации УВ по (Тектоническое..., 2006)

Fig. 5. Layout of potential and oil and gas-bearing terra-aquatic basins in the Southern part of the Sea of Okhotsk and the Pacific Ocean. After Tectonic..., 2006; Norton, 2007; Lomtev et al., 2016; Khomich et al., 2019, amended. 1 - basins and their boundaries: 1 - Okean, 2 - Mid-Kuril, 3 - South-Sakhalin, 4 - South-Okhotsk, 5 - Golygin, 6 - Deryugin, 7 North-Sakhalin, 8 - Shantar, 9 - Uchur-Maya (see Fig. 4); 2 - some known deposits of hydrocarbons; 3 - transform-type fault zones and linear magnetic anomalies of the ocean floor; 4 - other faults; 5 - assumed depth of the hydrocarbon generation centre, according to Tectonic..., 2006

2003; Hirano, 2011). Сопряженность проявлений щелочного магматизма с названными разлом- 
ными зонами, обеспечивающими восходящую миграцию водно-углеводородных флюидов по ослабленным проницаемым участкам сосдвигового растяжения (Касаткин, Обжиров, 2018), подтверждает контролирующее влияние глубинной (разломно-обусловленной) геодинамики на размещение нефтяных и газовых месторождений у местной зоны конвергенции. Фактическая протяженность разломных зон, контролирующих нефтегазоносность региона от поднятия Шатского в Тихом океане до Удской губы в западной части Охотского моря, составляет не менее 3000 км.

\section{ОБСУЖДЕНИЕ РЕЗУЛЬТАТОВ}

Приведенные в предыдущих разделах данные, раскрывая основные особенности строения нефтегазоносных районов на площади ЗападноСибирской плиты, западной окраины Сибирской платформы, Южно-Охотской провинции и северо-западной Циркумпацифики, свидетельствуют об исключительной роли глубинных долгоживущих разломов мантийного заложения в формировании и размещении залежей УВ. В последние годы получены доказательства принадлежности подобных нарушений к палеотрансформному типу (Khomich et al., 2019). Часто такие разломные зоны, особенно маркируемые у бортов рифтограбенов и депрессий, контролируют размещение и горстов, горстообразных поднятий в бассейнах осадконакопления, а также проявлений магматизма и эндогенного оруденения (Khomich et al., 2014). Для магматических образований, картируемых вблизи подобных глубинных разломов, характерна повышенная щелочность. Будь это вулканические и субвулканические тела шошонитов на океаническом дне у северо-западной окраины Тихоокеанской плиты в coopужениях типа «petit-spot» или кольцевые зональные плутоны (с дунитовым ядром) на юго-восточном фланге Северо-Азиатского кратона, как и сходные с ними другие ультраосновные массивы сложного генеза (Леснов, 2015) у восточного побережья о. Сахалин.

Исключительная роль глубинных разломов в качестве каналов миграции газов предполагает мантийно-абиогенное происхожение водноуглеводородных флюидов. Обозначенная гипотеза согласуется с известной концепцией эволюционного развития континентальной литосферы при формировании триады: земная кора - истощенная мантия - астеносфера. При этом астеносфера считается питающей средой флюидных систем, на базе которых формировались магматические очаги вулкано-плутонических поясов, зон и соответствующие им потоки (Летников, 2006). Астеносферная природа и восстановленность глубинных флюидных систем обеспечивали широкую проявленность в них тонкодисперс- ных выделений самородных элементов, которые присутствуют в высокотемпературных газовых струях.

Петрологи относительно давно обратили внимание на неизменное наличие флюидных включений метана и других более тяжелых УВ в минералах магматических щелочных пород (Маракушев и др., 2008). Подобные флюиды при миграции опережали иные восходящие дегазирующие потоки, а их окислительная полимеризация способствовала созданию высокого химического сродства с благородными металлами.

Результаты научных исследований последних лет в значительной мере подтверждают мантийно-абиогенную гипотезу нефтегазо- и рудообразования. Доказано, что потенциальным источником флюидов системы C-O-H могли быть ультрамафиты, поскольку водород и углерод присутствуют в структуре оливина и пироксена мантийных перидотитов в форме ионов $\mathrm{OH}^{-}$ и молекул $\mathrm{H}_{2} \mathrm{O}_{\text {cryst }}, \mathrm{CO}_{2}, \mathrm{CH}, \mathrm{CH}_{2}, \mathrm{CH}_{3}$ (Бабушкина и др., 2018). Среди летучих преобладает водная составляющая $\left(\mathrm{OH}^{-}+\mathrm{H}_{2} \mathrm{O}_{\text {cryst }}\right)$. Предполагается, что основным механизмом высвобождения летучих, представленных разными формами Н и $\mathrm{C}$, был процесс плавления. Новые экспериментальные доказательства миграции Pt в системе такого сверхкритического С-O-Н флюида (Летников и др., 2018) подтверждают реальность вышеобозначенного процесса. По изложенному сценарию сопряженность магмо- и рудогенеза с потоками УВ и нефтегазопроявлениями, казавшаяся прежде экзотической (Щеглов, 1980), может считаться естественной и закономерной. Обнаружение на островах южного звена Большой Курильской гряды высокотемпературных (до 940²) газовых струй, в составе которых присутствуют не только пары воды, но и $\mathrm{CO}_{2}, \mathrm{H}_{2}, \mathrm{H}_{2} \mathrm{~S}, \mathrm{HCl}$, $\mathrm{HF}, \mathrm{CH}_{4}$ и его гомологи, а также весьма сложные углеводородные комплексы (с платиной, фосфором, хлором), как и микрочастицы самородных платиноидов, меди, золота, рения и других элементов (Ткаченко и др., 1992; Знаменский и др., 1993; Коржинский и др., 1996; Yudovskaya et al., 2006; Дистлер и др., 2008; Разин, 2011; Шакиров, 2014), подкрепляют этот вывод. Пространственная сопряженность нефтегазовых и рудных районов с глубинными долгоживущими разломными зонами трансформного типа (Р3ТТ) дополнительно указывает на контролирующую роль последних. Именно они обеспечили столь аномальную проявленность и нефтегазогеохимических полей, и рудно-магматических узлов на Курилах и о. Сахалин (Данченко, 2003; Харахинов, 2010; Khomich et al., 2019).

Изложенные материалы хорошо согласуются с данными по другим регионам мира и теоретико-экпериментальными выкладками уче- 
ных, содержащими информацию о вероятном составе и строении корово-мантийного субстрата зон дивергенции и конвергенции. Так, исследование летучих компонентов из базальтовых стекол зоны одного из трансформных разломов Атлантики показало, что расплавы местной постройки были обогащены не только водой и калием, но и такими газами, как $\mathrm{CO}_{2}$ и $\mathrm{CH}_{4}$ (Симонов, 2006). При этом глубина выплавления первичного мантийного расплава (в аномальной системе типа E-MORB) от поверхности океанского дна составляла 80-110 км. Эти данные послужили В. А. Симонову основанием к выводу о том, что решающим фактором активного магматизма в зонах влияния трансформных разломов было их резкое обогащение щелочами и летучими компонентами. Подобное обогащение способствовало возникновению аномальных «флюидных точек» на океанском дне. Да и щелочной тип шошонитов из вулканов «petit-spot», размещенных на Тихоокеанской плите у Курильского желоба, согласуется с водно-углеводородным типом флюидов и газовых струй, проявленных в Южных Курилах на продолжении глубинных РЗТТ Носаппу, Итуруп, Уруп (Khomich et al., 2019).

Таким образом, петролого-геохимические свидетельства вероятности мантийно-абиогенного происхождения УВ (Сорохтин и др., 2001; Бабушкина и др., 2018) в совокупности с признаками восходящей миграции глубинных углеводородных флюидов в РЗТТ по участкам сосдвигового растяжения (Касаткин, Обжиров, 2018), как и сопряженность с ними проявлений щелочного магматизма (Hirano, 2011), доказывают решающее влияние глубинной геодинамики на размещение нефтегазоносных площадей. В деталях этот вывод подтверждается специализированными исследованиями смолисто-асфальтовых веществ нефтяных месторождений Сахалина, в которых, как уже отмечалось, присутствуют существенные количества элементов платиновой группы (ЭПГ). При этом одним из факторов увеличения содержаний ЭПГ в нефти считается водородная или метановая ее дегазация (Маракушев и др., 2014). Поэтому данные о повышенных концентрациях благородных металлов в сольфатарах, грязевых котлах, горячих источниках и газовых струях активных вулканов на южнокурильских островах (Yudovskaya et al., 2006; Дистлер и др., 2008; Разин, 2011; Khomich et al., 2019) объясняют факты пространственной сопряженности нефтегазовых и рудно-магматических узлов.

Из приведенного синтеза геолого-геофизических и петролого-геохимических материалов, раскрывающего особенности происхождения и позиции нефтегазоносных площадей в северной половине Азиатского континента и северо-за- падной части Циркумпацифики, следует, что на обозначенной территории возможно существование крупных структур, обладающих набором необходимых поисково-оценочных признаков в пользу их нефтегазоносности, но еще недостаточно изученных и опоискованных. Одними из таких потенциально перспективных площадей на юго-восточной окраине Сибирской платформы представляются Учурская и Майская СФЗ. В пределах клина Учурской зоны известно несколько рифтограбенов (Маймаканский, Уганский, Учурский и др.), обладающих мощным (в несколько километров) разрезом из протерозойских и рифейских толщ, где, вероятно, имелись условия для сохранения горячих флюидопотоков, насыщенных УВ, проникающих из мантийных глубин по РЗТТ. В пределах названных СФЗ имеются и горстообразные поднятия фундамента, усложняющие их строение. Перечисленными признаками (наличие рифтограбенов, депрессий, горстов, осадочных разрезов значительной мощности, магматитов повышенной щелочности, присутствие ЭПГ и геофизических аномалий, включая тепловые) юго-восточный фланг Сибирской платформы в определенной степени напоминает западную окраину. $\mathrm{K}$ тому же в названных СФЗ активно проявились процессы магматизма и рудообразования (Гурович и др., 1994; Полин и др., 2012; Ронкин и др., 2013; Хомич, Борискина, 2014). Именно здесь обнаружены зональные дунит-перидотит-габбро-гранитоидные плутоны с благороднометалльным (Au + PGE) оруденением (Khomich et al., 2014), первоисточники которых располагались в транзитной (410670 км) мантии и могли мигрировать по «местным» ЗСЗ палеотрансформным разломным зонам. В зоне влияния последних известно еще несколько зональных (с дунитовым ядром) платиноносных массивов: на о. Феклистов (Шантарский архипелаг), Инагли в Центрально-Алданском районе и др. Не случайно специалисты считают и Шантарскую площадь, и Курильскую котловину, и Средне-Курильский бассейн потенциально нефтегазоносными (Тектоническое..., 2006; Маракушев, Маракушев, 2008). Привлекает внимание и сосредоточенность перечисленных площадей в единой ЗС3 линейной зоне (над глубинными РЗТТ) протяженностью более 3.5 тыс. км.

Из приведенных выводов следует, что в Азиатско-Тихоокеанской мегазоне взаимодействия с глубинными, протяженными долгоживущими РЗТТ северо-западной ориентации не случайно пространственно сопряжены и нефтегазоносные, и рудоносные площади. Это заключение согласуется с мнением ряда исследователей о возможности формирования месторождений УВ на юге Сибирской платформы «...за счет субвертикальных флюидных потоков из подфунда- 
ментных источников...под влиянием периодической активизации разломных систем различной пространственной ориентации» (Берзин и др., 2019. С. 11). Оно позволяет рассматривать террааквальные территории и Шантарского архипелага в Охотском море, и Учурской, а также Майской СФЗ на юго-восточной окраине Алданской антеклизы Сибирской платформы в качестве потенциально перспективных на возможное выявление нефтегазоносных площадей и залежей.

\section{ЗАКЛЮЧЕНИЕ}

Обоснование возможной нефтегазоносности юго-восточной окраины Сибирской платформы в целом и ее Алданской антеклизы, а также рифтограбенов и депрессий Учурской, Майской СФЗ, в частности, предполагает более детальный анализ имеющихся по этой территории геолого-геофизических материалов в целях выбора мест возможного заложения структурнопараметрических скважин для доизучения разрезов и определения участков вероятной концентрации УВ.

\section{ЛИТЕРАТУРА}

Бабушкина М. С., Уголков В. Л., Марин Ю. Б., Никитина Л. П., Гончаров А. Г. Водородные и углеродные группировки в структурах породообразующих минералов пород литосферной мантии: данные FTIR и STA + OMS // ДАН. 2018. Т. 479, № 4. С. 426-429.

Баженова Т. К., Маргулис Л. С. Нефтегазообразование в Алдано-Майском бассейне Сибирской платформы // Нефтегазовая геология, теория и практика. 2014. T. 9, № 4. C. 1-18.

Берзин А. Г., Марсанова М. Р., Третьяков М. Ф., Берзин С. А. Активизированная разломная тектоника и формирование залежей УВ в осадочно-породном бассейне на юге Сибирской платформы // Разведка и охрана недр. 2019. № 2. С. 11-19.

Варнавский В. Г., Кузнеиов В. Е. Область рифейвенд-кембрийского седиментогенеза юго-восточной окраины Северо-Азиатского кратона // Тихоокеанская геология. 2011. Т. 31, № 5. С. 67-79.

Высочкий С. В., Говоров Г. И., Кемкин И. В., Сапин $B$. И. Бонинит-офиолитовая ассоциация Восточного Сахалина : геология и некоторые особенности петрогенезиса // Там же. 1998. Т. 17, № 6. С. 3-15.

Гладенков Ю. В., Баженова О. К., Гречин В. И., Маргулис Л. С., Сальников Б. А., Гурович В. Г., Емельяненко Е. П., Землянухин В. Н., Каретников А. С., Квасов А. И., Лазаренков В. Г., Малич К. Н., Мочалов А. Г., Приходько В. С., Степашко А. А. Геология, петрология и рудоносность Кондерского массива. М. : Наука, 1994. 170 с.

Гурьянов В. А., Песков А. Ю. Улканская палеорифтовая структура: особенности развития, геодинамическая обстановка (юго-восточное обрамление Сибирской платформы) // Региональная геология и металлогения. 2015. № 62. С. 57-63.

Данченко B. Я. Геологическое положение и вещественно-генетические типы оруденения редких и благородных металлов в Южно-Охотском регионе Тихоокеанского обрамления. Ю.-Сахалинск : ИМГиГ Сах. науч. центра ДВО РАН, 2003. 227 с.

Дистлер В. В., Диков Ю. П., Юдовская М. А., Чапльгин И. В., Булеев М. И. Платино-хлор-фосфоруглеводородные комплексы в вулканических флюидах - первая находка в земной обстановке // ДАН. 2008. Т. 420, № 2. С. 217-220.

Жаров А. Э. Геологическое строение и мел-палеогеновая геодинамика Юго-Восточного Сахалина. Ю.-Сахалинск : Кн. изд-во, 2004. 191 с.

Знаменский В. С., Лапутина И. П., Таран Ю. А., Якушев А. И. Рудоотложение из высокотемпературных газовых струй вулкана Кудрявый, о. Итуруп, Курильские острова // ДАН СССР. 1993. Т. 333, № 2. C. 227-230.

Зоненшайн Л. П., Кузьмин М. И. Палеогеодинамика. М. : Наука, 1992. 192 с.

Иванов К. С., Лач С. А., Коротеев В. А., Костров H. А., Погромская О. Э. Главные причины закономерности размещения месторождений нефти ЗападноСибирской платформы // ДАН. 2018. Т. 481, № 3. C. 285-288.

Кайнозой Сахалина и его нефтегазоносность. М. : ГЕОС, 2002. $225 \mathrm{c}$.

Касаткин С. А., Обжиров А. И. Флюидоконтролирующее значение разломной зоны Носаппу и условия формирования потоков метана и залежей газогидратов (Охотоморский регион) // Тихоокеанская геология. 2018. Т. 37, № 1. С. 61-66.

Конторович А. Э., Изосимова А. Н., Конторович А. А., Хабаров Е. М., Тимошина И. Д. Геологическое строение и условия формирования гигантской Юрубчено-Тохомской зоны нефтенакопления в верхнем протерозое Сибирской платформы // Геология и геофизика. 1996. Т. 37, № 8. С. 166-195.

Коржинский М. А., Ткаченко С. И., Булгаков Р. Ф., Шмулович К. И. Составы конденсатов и самородные металлы в сублиматах высокотемпературных газовых струй вулкана Кудрявый (остров Итуруп, Курильские острова) // Геохимия. 1996. № 12. С. 1175-1182.

Кузнецов В. Е., Варнавский В. Г. Венд-рифейские комплексы Алдано-Майского осадочного бассейна и Юрубчено-Тохомской зоны нефтегазонакопления (юго-восток и юго-запад Северо-Азиатского кратона): сравнительный анализ, нефтегазоносность // Тихоокеанская геология. 2018. Т. 37, № 1. С. 22-36.

Кузьмин М. И., Ярмолюк В. В. Мантийные плюмы Северо-Восточной Азии и их роль в формировании эндогенных месторождений // Геология и геофизика. 2014. T. 55, № 2. C. 153-184.

Леснов В. П. Петрология полигенных мафитультрамафитовых массивов Восточно-Сахалинской офиолитовой ассоциации. Новосибирск : Акад. изд-во «Гео», 2015. 240 c.

Летников Ф. А., Шумилова Т. Г., Медведев В. Я., Иванова Л. А. Транспорт и кристаллизация самородной платины в условиях сверхкритического C-O-Hфлюида // ДАН. 2018. Т. 479, № 4. С. 430-432.

Летников Ф. А. Флюидный режим эндогенных процессов и проблемы рудогенеза // Геология и геофизика. 2006. Т. 47, № 12. С. 1296-1308.

Ломтев В. Л., Веселов О. В., Козлов Д. Н., Кочергин А. В., Кочергин Е. В., Лютая Л. М., Семакин В. П., 
Сеначин В. Н., Сеначин М. В., Паровышиный В. Н., Патрикеев В. Н., Тихонов И. Н. Особенности строения и геодинамики тектоносферы северо-западной части Тихого океана и дальневосточных морей / отв. ред. В. Г. Варнавский, А. И. Обжиров, А. В. Савицкий. Владивосток : Дальнаука, 2016. 147 с.

Маракушев А. А., Маракушев С. А. Образование нефтяных и газовых месторождений // Литология и полезные ископаемые. 2008. № 5. С. 505-521.

Маракушев А. А., Емельяненко Е. П., Некрасов И. Я., Масловский А. Н., Залищак Б. Л. Формирование концентрически зональной структуры Кондерского щелочно-ультраосновного массива // ДАН СССР. 1990. T. 311, № 1. С. 167-170.

Маракушев А. А., Панеях Н. А., Маракушев С. А. Сульфидное образование и его углеводородная специлизация. М. : ГЕОС, 2014. 184 с.

Мишукова Г. Г., Шакиров Р. Б., Обжиров А. И. Потоки метана на границе вода - атмосфера в Охотском море // ДАН. 2017. Т. 475, № 6. С. 697-701.

Никифоров В. М., Шкабарня Г. Н., Жуковин А. Ю., Каплун В. Б., Талтыкин Ю. В. Новый подход к изучению блокового геоэлектрического строения литосферы и флюидонасыщенных фрагментов разломов как индикаторов зон повышенной сейсмичности (по данным МТЗ на Южном Сахалине) // Тихоокеанская геология. 2018. Т. 37, № 4. С. 44-55.

Полин В. Ф., Мицук В. В., Ханчук А. И., Глебовичкий В. А., Будниикий С. Ю., Ризванова Н. Г., Соляник A. Н., Шишов А. С. Геохронологические рубежи субщелочного магматизма Кеткапско-Юнской магматической провинции Алданского щита // ДАН. 2012. T. 442, № 1. С. 83-89.

Разин Л. В. Современная вулканогенная платиновая металлоносность и золотоносность на острове Кунашир, генетически связанная с молодым андезитбазальтовым вулканизмом Большой Курильской гряды // Платина России : сб. науч. тр. Красноярск, 2011. T. 7. C. 476-493.

Ронкин Ю. Л., Ефимов А. А., Лепихина Г. А., Родионов Н. В., Маслов А. B. U-Pb-датирование системы «бадделеит - циркон» платиноносного дунита Кондерского массива (Алданский щит): новые данные // ДАН. 2013. Т. 450, № 5. С. 579-585.

Сапрыгин С. М. Тектоническая флюидодинамика. Ю.-Сахалинск : Кн. изд-во, 1997. 80 с.

Симонов $B$. A. Влияние флюидных компонентов на магматические системы «горячих точек» // Материалы Всерос. симп. «Флюиды и геодинамика». М. : Наука, 2006. С. 260-274.

Сорохтин О. Г., Леин А. Ю., Баланюк И. Е. Термодинамика океанических гидротермальных систем и абиогенная генерация метана // Океанология. 2001. T. 41, № 6. С. 898-909.

Тектоническое районирование и углеводородный потенциал Охотского моря / ред. К. Ф. Сергеев. М. : Наука, 2006. 129 с.

Ткаченко С. И., Таран Ю. А., Коржинский А. М., Покровский В. Г., Штейнберг Г. С., Шмулович К. И. Газовые струи вулкана Кудрявый, о. Итуруп, Курильские острова // ДАН СССР. 1992. Т. 325, № 4. С. $823-$ 828.

Харахинов В. В. Нефтегазовая геология Сахалинского региона. М. : Науч. мир, 2010. 275 с.
Харахинов В. В., Шленкин С. И., Зеренинов В. А. Нефтегазоносность докембрийских толщ Куюмбинско-Тохомского ареала нефтегазонакопления // Нефтегазовая геология. Теория и практика. 2011. Т. 6, № 1. C. 1-30.

Хомич В. Г., Борискина Н. Г. Геодинамические, тектонические и магматические индикаторы крупных урановорудных узлов Забайкальско-МонголоСеверокитайской провинции // Тихоокеанская геология. 2018. Т. 37, № 6. С. 39-52.

Хомич В. Г., Борискина Н. Г. Глубинная геодинамика Юго-Востока России и позиция платиноносных базит-гипербазитовых массивов // Вулканология и сейсмология. 2013. № 5. С. 40-50.

Хомич В. Г., Борискина Н. Г. Особенности размещения платинометалльной минерализации на ЮгоВостоке России // Геология и геофизика. 2014. Т. 55, № 7. C. 1065-1080.

Челноков Г. А., Жарков Р. В., Брагин И. В., Веселов О. В., Харитонова Н. А., Шакиров Р. Б. Геохимические характеристики подземных флюидов южной части Центрально-Сахалинского разлома // Тихоокеанская геология. 2015.T. 34, № 5. С. 8195.

Шакиров Р. Б., Сырбу Н. С., Обжиров А. И. Изотопно-геохимические особенности распределения метана и углекислого газа на острове Сахалин и прилегающем шельфе Охотского моря // Вестник КРАУНЦ. Науки о Земле. 2012. Т. 20, № 2. С. 100113.

Шакиров Р. Б. Особенности химического и изотопного состава углеводородных газов вулканов Менделеева и Головнина (о. Кунашир) // Геохимия. 2014. Т. 52, № 3. С. 267-279.

Шемин Г. Г., Мигурский А. В., Смирнов М. Ю., Леонтьев И. Ю., Бондарев А. Н., Моисеев С. А., Вахромеев А. Г., Поспеев А. В., Станевич А. М. Перспективы нефтегазоносности региональных резервуаров Предпатомского регионального прогиба (Сибирская платформа) / отв. ред. М. И. Эпов. Новосибирск : Изд-во CO PAH, 2018. $315 \mathrm{c}$.

Шуколюков Ю. А., Якубович О. В., Мочалов Г. К., Котов А. Б., Сальникова Е. Б., Яковлева С. З., Корнеев С. И., Гороховский Б. М. Новый изотопный геохронометр для прямого датирования самородных минералов платины $\left({ }^{190} \mathrm{Pt}-{ }^{4} \mathrm{He}\right.$ метод) // Петрология. 2012. Т. 20, № 6. С. 545-559.

Щеглов А. Д. Основы металлогенического анализа. М. : Недра, 1980. 431 с.

Hirano N. Petit-spot volcanism: A new type of volcanic zone discovered near a trench // Geochemical Journal. 2011. No. 45. P. 157-167.

Khomich V. G., Boriskina N. G., Santosh M. A geodynamic perspective of world-class gold deposits in East Asia // Gondwana Research. 2014. Vol. 26, No. 3-4. P. 816-833. DOI: 10.1016/j.gr.2014.05.007

Khomich V. G., Boriskina N. G., Fatyanov I. I., Santosh $M$. Characteristics and genesis of the Mnogovershinnoe gold-silver deposit, SE Russia // Ore Geology Reviews. 2018. No. 103. P. 56-67. https://doi.org/10.1016/j. oregeorev.2017.01.017

Khomich V. G., Boriskina N. G., Kasatkin S. A. Geology, magmatism, metallogeny, and geodynamics of the South Kuril Islands // Ore Geology Reviews. 
2019. No. 105. P. 151-162. https://doi.org/10.1016/j. oregeorev.2018.12.015

Khomich V. G., Boriskina N. G. Deep-seated geodynamics and position of platinum-bearing basiteultrabasite massifs of South-East Russia // Global Geology. 2012. No. 15. P. 204-209. DOI: 10.3969/j. issn.1673-9736.2012.03.02

Korzhinskii M. A., Tkachenko S. I., Shmulovich K. I., Taran, Y. A.; Steinberg, G. S. Discovery of pure rhenium mineral at Kudriavy volkano // Nature. 1994. No. 369. P. 51-52.

Norton I. O. Speculations on Cretaceous tectonic history of the northwest Pacific and a tectonic origin for the Hawaii hotspot // Special Paper of the Geological Society of America. 2007. No. 430. P. 451-470.

Ogawa Y., Hirano $N$. En echelon knolls in the Nosappu Fracture Zone, NW Pacific: A possible leaky transform fault zone II Shipboard Scientific Party Kr0307 // American Geophysical Union. Fall Meeting. 2003. Abstract \#V21D-0553

Yudovskaya M. A., Distler V. V., Chaplygin I. V., Mokhov A. V., Trubkin N. V., Gorbacheva S. A. Gaseous transport and deposition of gold in magmatic fluid: evidence from the active Kudryavy volcano, Kurile Islands // Mineralium Deposita. 2006. No. 40. P. 828-848. https://doi. org/10.1007/s00126-005-0034-6

\title{
ON THE POSSIBLE OIL AND GAS POTENTIAL OF RIFT GRABENS IN THE UCHUR AND MAYA ZONES AT THE ALDAN ANTECLISE'S SOUTHEASTERN FLANK (Siberian Platform)
}

\author{
V. G. Khomich, N. G. Boriskina
}

\author{
Far East Geological Institute FEB RAS, Vladivostok
}

\begin{abstract}
Based on the comparative analysis of structural particularities and geodynamic conditions of the development of oil-and-gas-bearing complexes of the West Siberian plate, the Siberian craton, as well as those in sedimentary basins of Northern Sakhalin and its shelves, the authors substantiate the possibility of exposing hydrocarbon deposit occurrences in the Uchur and Maya structure-facial zones of of the Aldan anteclise at the Siberian platform's southeastern margin.
\end{abstract}

Keywords: Aldan anteclise, rift grabens, Siberian craton, depressions, paleotransform faults, hydrocarbons, geochemical anomalies.

\section{REFERENCES}

Babushkina, M. S.; Ugolkov, V.L.; Marin, Yu. B.; Nikitina, L. P.; Goncharov, A. G., 2018, Hydrogen and Carbon Groups in the Structures of Rock-Forming Minerals of the Lithospheric Mantle Rocks: FTIR and STA + QMS Data, Doklady Earth Sciences, 479, 4, 456-459 [In Russian], https://doi.org/10.1134/S1028334X18040013

Bazhenova, T. K.; Margulis, L. S., 2014, Oil and Gas Formation in the Aldan-May Basin of the Siberian Platform, Petroleum Geology - Theoretical and Applied Studies, 9, 4, 1-18 [In Russian].

Berzin, A. G.; Marsanova, M. R.; Tretyakov, M. F.; Berzin, S. A., 2019, Activated Fault Tectonics and Formation of Hydrocarbon Deposits in the Sedimentary-Rock Basin in the South of the Siberian Platform, Prospect and Protection of Mineral Resources, 2, 11-19 [In Russian].

Cenozoic of Sakhalin and Its Oil-and-Gas Bearing Potential, 2002, Moscow, GEOS [In Russian].

Chelnokov, G. A.; Zharkov, R. V.; Bragin, I. V.; Veselov, O. V.; Kharitonova, N. A.; Shakirov, R. B., 2015, Geochemical Characteristics of Subterranean Fluids in the Southern Part of the Central Sakhalin Fault, Russian Journal of Pacific Geology, 34, 5, 81-95 [In Russian].

Danchenko, V. Ya., 2003, Geological Position and Real-Genetic Types of Mineralization of Rare and Noble
Metals in the South Okhotsk Region of the Pacific Rim, Yuzhno-Sakhalinsk, IMGiG Sakh. Scientific Center of FEB RAS [In Russian].

Distler, V. V.; Dikov, Yu. P.; Yudovskaya, M. A.; Chaplygin, I. V.; Чапльгин, И. В.; Булеев, М. И., 2008, Platinum-Chlorine-Phosphorus-Hydrocarbon Complex in Volcanic Fluids: The First Find in the Terrestrial Environment, Doklady Earth Sciences, 420, 628-631, DOI: 10.1134/S1028334X08040223

Gladenkov, Yu. V.; Bazhenova, O. K.; Grechin, V. I.; Margulis, L. S.; Sal'nikov, B. A., Gurovich, V. G.; Yemelyanenko, Ye. P.; Zemlyanukhin, V. N.; Karetnikov, A. S.; Kvasov, A. I.; Lazarenkov, V. G.; Malich, K. N.; Mochalov, A. G.; Prikhod'ko, V. S.; Stepashko, A. A., 1994, Geology, Petrology, and Mineralization of the Konder Massif, Moscow, Nauka [In Russian].

Guryanov, V. A.; Peskov, A. Yu., 2015, Ulkansk Paleorift Structure: Development Features, Geodynamic Setting (Southeast Framing of the Siberian Platform), Regional Geology and Metallogeny, 62, 57-63 [In Russian].

Hirano, N., 2011, Petit-Spot Volcanism: A New Type of Volcanic Zone Discovered Near a Trench, Geochemical Journal, 45, 157-167.

Ivanov, K. S.; Lats, S. A.; Koroteyev, V. A.; Kostrov, N. A.; Pogromskaya, O. E., 2018, Main Factors Affecting 
the Distribution of Oil Fields in the West Siberian Platform, Doklady Earth Sciences, 481, 873-876, https://doi. org/10.1134/S1028334X18070218

Kasatkin, S. A.; Obzhirov, A. I., 2018, Fluid-Controlling Significance of the Nosappu Fracture Zone and Conditions for the Formation of Methane Fluxes and Gas Hydrates (Sea of Okhotsk Region), Russian Journal of Pacific Geology, 12, 57-62, https://doi.org/10.1134/ S1819714018010025

Kharakhinov, $V . V ., 2010$, Oil and Gas Geology of the Sakhalin Region. Moscow, Nauchnyi Mir [In Russian].

Kharakhinov, V. V.; Shlenkin, S. I.; Zereninov, V. A., 2011, Oil and Gas Potential of Precambrian Strata of the Kuyumba-Tokhomo Area of Oil and Gas Accumulation, Petroleum Geology - Theoretical and Applied Studies, 6, 1, 1-30 [In Russian].

Khomich, V. G.; Boriskina, N. G., 2012, Deep-Seated Geodynamics and Position of Platinum-Bearing Basite-Ultrabasite Massifs of South-East Russia, Global Geology, 15, 204-209, DOI: 10.3969/j.issn.1673-9736. 2012.03.02

Khomich, V. G.; Boriskina, N. G., 2013, Deep Geodynamics of Southeast Russia and the Setting of Platinum-Bearing Basite-Hyperbasite Massifs, Journal of Volcanology and Seismology, 7, 5, 328-337, DOI: 10.1134/ S0742046313040040

Khomich, V. G.; Boriskina, N. G., 2014, Localization of PGE Mineralization in Southeastern Russia, Russian Geology and Geophysics, 55, 7, 842-853, DOI: 10.1016/j. rgg.2014.06.004 (IF-1,308)

Khomich, V. G.; Boriskina, N. G., 2018, Geodynamic, Tectonic, and Magmatic Indicators of Large Uranium Clusters of the Transbaikal-Mongolia - North China Province, Russian Journal of Pacific Geology, 12, 6, 487-499, DOI: 10.30911/0207-4028-2018-37-6-3952

Khomich, V. G.; Boriskina N. G.; Fatyanov, I. I.; Santosh, M., 2018, Characteristics and Genesis of the Mnogovershinnoe Gold-Silver Deposit, SE Russia, Ore Geology Reviews, 103, 56-67, https://doi.org/10.1016/j. oregeorev.2017.01.017

Khomich, V. G.; Boriskina, N. G.; Kasatkin, S. A., 2019, Geology, Magmatism, Metallogeny, and Geodynamics of the South Kuril Islands, Ibid., 105, 151-162, https://doi.org/10.1016/j.oregeorev.2018.12.015

Khomich, V. G.; Boriskina, N. G.; Santosh, M., 2014, A Geodynamic Perspective of World-Class Gold Deposits in East Asia, Gondwana Research, 26, 3-4, 816-833, DOI: 10.1016/j.gr.2014.05.007

Kontorovich, A. E.; Izosimova, A. N.; Kontorovich, A. A.; Khabarov, Ye. M.; Timoshina, I. D., 1996, Geological Structure and Conditions for the Formation of the Giant Yurubchen-Tokhomo Oil Accumulation Zone in the Upper Proterozoic of the Siberian Platform, Geology and Geophysics, 37, 8, 166-195 [In Russian].

Korzhinskii, M. A.; Tkachenko, S. I.; Shmulovich, K. I.; Taran, Y. A.; Steinberg, G. S., 1994, Discovery of Pure Rhenium Mineral at Kudriavy Volkano, Nature, 369, 51-52.

Korzhinsky, M. A.; Tkachenko, S. I.; Bulgakov, R. F.; Shmulovich, K. I., 1996, Condensate Compositions and Native Metals in Sublimates of High-Temperature Gas Jets of the Kudryavyi Volcano, Iturup Island, Kuril Islands, Geochemistry International, 34, 1057-1064.
Kuz'min, M. I.; Yarmolyuk, V. V., 2014, Mantle Plumes of Northeast Asia and Their Role in Forming Endogenous Deposits, Russian Geology and Geophysics, 55, 2, 120 143, DOI: 10.1016/j.rgg.2014.01.002

Kuznetsov, V. E.; Varnavsky, V. G., 2018, VendianRiphean Complexes of the Aldan-Maya Sedimentary Basin and the Yurubchen-Tokhomo Zone of Oil-and-Gas Accumulation, South-East and South-West of the North Asian Craton: Comparative Analysis and Petroleum Potential, Russian Journal of Pacific Geology, 12, 20-33, DOI: $10.1134 / \mathrm{S} 1819714018010049$

Lesnov, V. P., 2015, Petrology of Polygenic Mafic-U1tramafic Massifs of the East-Sakhalin Ophiolitic Association, Novosibirsk, Geo [In Russian].

Letnikov, F. A., 2006, Fluid Regime of Endogenous Processes and Problems of Ore Genesis, Russian Geology and Geophysics, 47, 12, 1296-1308 [In Russian].

Letnikov, F. A.; Shumilova, T. G.; Medvedev, V. Ya.; Ivanova, L. A., 2018, Transportation and Crystallization of Noble Platinum in the Supercritical C-O-H Fluid Conditions, Doklady Earth Sciences, 479, 460-462, https:// doi.org/10.1134/S1028334X18040049

Lomtev, V. L.; Veselov, O. V.; Kozlov, D. N.; Kochergin, A. V.; Kochergin, Ye. V.; Lyutaya, L. M.; Semakin, V. P.; Senachin, V. N.; Senachin, M. V.; Parovyshny, V. N.; Patrikeyev, V. N.; Tikhonov, I. N., 2016, Features of the Structure and Geodynamics of Tectonosphere in the Northwestern Part of the Pacific Ocean and the Far East Seas, Eds. V. G. Varnavsky, A. I. Obzhirov, A. V. Savitsky, Vladivostok, Dalnauka [In Russian].

Marakushev, A. A.; Marakushev, S. A., 2008, Formation of Oil and Gas Fields, Lithology and Mineral Resources, 5, 505-521 [In Russian].

Marakushev, A. A.; Paneyakh, N. A.; Marakushev, S. A., 2014, Sulphide Formation and its Hydrocarbon Specialization, Moscow, GEOS [In Russian].

Marakushev, A. A.; Yemelyanenko, Ye. P.; Nekrasov, I. Ya.; Maslovsky, A. N.; Zalishchak, B. L., 1990, Formation of the Concentrically Zonal Structure of the Konder Alcaline-Ultrabasic Massif, Doklady Akademiyi Nauk SSSR, 11, 1, 167-170 [In Russian].

Mishukova, G. G.; Shakirov, R. B.; Obzhirov, A. I., 2017, Methane Fluxes on the Water - Atmosphere Boundary in the Sea of Okhotsk, Doklady Earth Sciences, 475, 963-967, https://doi.org/10.1134/S1028334X17080256

Nikiforov, V. M.; Shkabarnya, G. N.; Zhukovin, A. Yu.; Kaplun, V. B.; Taltykin, Yu. V., 2018, New Approach to the Study of the Block Geoelectric Structure of the Lithosphere and Fluid-Saturated Fragments of Faults as Indicators of Zones with Increased Seismicity, According to Magnetotelluric Sounding Data for Southern Sakhalin, Russian Journal of Pacific Geology, 12, 278288, https://doi.org/10.1134/S1819714018040048

Norton, I. O., 2007, Speculations on Cretaceous Tectonic History of the Northwest Pacific and a Tectonic Origin for the Hawaii Hotspot, Special Paper of the Geological Society of America, 430, 451-470.

Ogawa, Y.; Hirano, N., 2003, En Echelon Knolls in the Nosappu Fracture Zone, NW Pacific: A Possible Leaky Transform Fault Zone II Shipboard Scientific Party Kr0307, American Geophysical Union. Fall Meeting, Abstract \#V21D-0553

Polin, V. F.; Mitsuk, V.V.; Khanchuk, A. I.; Glebovitsky, V. A.; Budnitsky, S. Yu.; Rizvanova, N. G.; Solyanik, A. N.; 
Shishov, A. S., 2012, Geochronological Boundaries of Subalkaline Magmatism in the Ket-Kap-Yuna Igneous Province, Aldan Shield, Doklady Earth Sciences, 442, 1, 17-23. DOI: 10.1134/S1028334X12010096

Razin, L. V., 2011, Recent Volcano Genesis Platinum and Gold Bearing Mineralisation on Kunashyr Island Related to Young Andesite-Basalt Volcanism of the Greater Kuril Ridge, Platinum of Russia, Collection of Scientific Papers, Krasnoyarsk, 7, 476-493 [In Russian].

Ronkin, Yu. L.; Efimov, A. A.; Lepikhina, G. A.; Rodionov, N. V.; Maslov, A. V., 2013, U-Pb Dating of the Baddeleytte-Zircon System from the Pt-bearing Dunite of the Konder Massif, Aldan Shield: New Data, Doklady Earth Sciences, 450, 2, 607-612, DOI: 10.1134/ S1028334X13060135

Saprygin, S. M., 1997, Tectonic Fluid Dynamics, Yuzhno-Sakhalinsk [In Russian].

Shakirov, R. B., 2014, Chemical and Isotopic Characteristics of Hydrocarbon Gases from the Mendeleev and the Golovnin Volcanoes, Kunashir Island, Geochemistry International, 52, 247-259, https://doi.org/10.1134/ S0016702914010066

Shakirov, R. B.; Syrbu, N. S.; Obzhirov, A. I., 2012, Isotope-Geochmical Features of Methane and Carbon Dioxid Distribution on Sakhalin Island and the Adjacent Shelf of the Sea of Okhotsk, Bulletin of KRAESC. Earth Sciences, 20, 2, 100-113 [In Russian].

Shcheglov, A. D., 1980, Basics of the Metallogenic Analysis, Moscow, Nedra [In Russian].

Shemin, G. G.; Migursky, A. V.; Smirnov, M. Yu.; Leontyev, I. Yu.; Bondarev, A. N.; Moiseev, S. A.; Vakhromeyev, A. G.; Pospeyev, A. V.; Stanevich, A. M., 2018, Prospects for the Oil and Gas Potential of the Regional Reservoirs in the Prepatomsky Regional Downwarp (Siberian Platform), Ed. M. I. Epov, Novosibirsk, SB RAS [In Russian].

Shukolyukov, Yu. A.; Yakubovich, O. V.; Mochalov, G. K.; Kotov, A. B.; Salnikova, E. B.; Yakovleva, S. Z.; Korneev, S. I.; Gorokhovskii, B. M., 2012, New Isotopoic Geochronometer for the Direct Isotopic Dating of Native Platinum Minerals $\left({ }^{190} \mathrm{Pt}-{ }^{4} \mathrm{He}\right.$ Method), Petrology, 20, 6, 491-505, DOI: 10.1134/S0869591112060033 [In Russian].
Simonov, V. A., 2006, Influence of Fluid Components on Magmatic Systems of "Hot Spots", Fluids and Geodynamics: Materials of the Symp. "Deep-Sourced Fluids and Geodynamics", Moscow, Nauka, 260-274 [In Russian].

Sorokhtin, O. G.; Lein, A. Yu.; Balanyuk, I. E., 2001, Thermodynamics of Oceanic Hydrothermal Systems and Abiogenic Generation of Methane, Oceanology, 41, 6, 898-909 [In Russian].

Tectonic Zoning and Hydrocarbon Potential of the Okhotsk Sea, Ed. K. F. Sergeev, Yuzhno-Sakhalinsk [In Russian].

Tkachenko, S. I.; Taran, Yu. A.; Korzhinsky, A. M.; Pokrovsky, V. G.; Shteinberg, G. S.; Shmulovich, K. I., 1992, Gas Jets of the Kudryavy Volcano, Iturup Island, Kuril Islands, Doklady Akademiyi Nauk SSSR, 325, 4, 823-828 [In Russian].

Varnavsky, V. G.; Kuznetsov, V. E., 2011, The Riphean-Vendian-Cambrian Sedimentogenesis Zone at the Southeastern Margin of the North Asian Craton: Geostructural Setting and Regionalization, Russian Journal of Pacific Geology, 5, 5, 433-445, DOI: 10.1134/ S1819714011050101

Vysotskii, S. V.; Govorov, G. I.; Kemkin, I. V.; Sapin, V. I., 1998, Boninite-Ophiolite Association of Eastern Sakhalin: Geology and Some Features of Petrogenesis, Ibid., 17, 6, 3-15 [In Russian].

Yudovskaya, M. A.; Distler, V. V.; Chaplygin, I. V.; Mokhov, A. V., Trubkin, N. V.; Gorbacheva, S. A., 2006, Gaseous Transport and Deposition of Gold in Magmatic Fluid: Evidence from the Active Kudryavy Volcano, Kurile Islands, Mineralium Deposita, 40, 828-848, https://doi. org/10.1007/s00126-005-0034-6

Zharov, A. E., 2004, Geological Structure and Cretaceous-Paleogene Geodynamics of Southeastern Sakhalin, Yuzhno-Sakhalinsk [In Russian].

Znamensky, V. S.; Laputina, I. P.; Taran, Yu. A.; Yakushev, A. I., 1993, Ore Deposition from High-Temperature Gas Jets of the Kudryavy Volcano, Iturup, Kurile Islands, Doklady AN SSSR, 333, 2, 227-230 [In Russian].

Zonenshain, L. P.; Kuz'min, M. I., 1992, Paleogeodynamics, Moscow, Nauka [In Russian]. 